Colombo C.G. Tassinari ${ }^{1}$, José M. U.Munhá ${ }^{2}$, Wilson Teixeira ${ }^{1}$, Teresa Palácios ${ }^{2}$, Allen P. Nutman ${ }^{3}$, Cesar Sosa S. ${ }^{4}$, Adjair P. Santos ${ }^{5}$, and Bruno O. Calado ${ }^{1}$

\title{
The Imataca Complex, NW Amazonian Craton, Venezuela: Crustal evolution and integration of geochronological and petrological cooling histories
}

\author{
1 Centro de Pesquisas, Geocronológicas Instituto de Geociências, Universidade de São Paulo, Rua do Lago 562, Cidade Universitária, \\ Butantã, São Paulo, Brasil. CEP 05588-900, E-mail: ccgtassi@usp.br \\ 2 Centro/Dept. Geologia, Edifício C2, $5^{\circ}$ piso, Faculdade Ciências, Universidade de Lisboa, Campo Grande, 1749-016 Lisboa, Portugal. \\ 3 Research School of Earth Sciences, Australian National University. \\ 4 Ministerio de Minas de Venezuela, Ciudad Bolivar. \\ 5 Cia. Minera SOPEVEN, Venezuela.
}

SHRIMP U/Pb-zircon data and Nd mean crustal residence ages indicate that the Imataca Complex developed from an Archean $(\geq 3.2 \mathrm{Ga}$ ) continental protolith which has undergone considerable isotopic disturbance plus and juvenile accretion during late-Archean $(\sim 2.8$ $\mathrm{Ga}$ ) times. Transamazonian granulites experienced peak metamorphic conditions of $750-800{ }^{\circ} \mathrm{C}, 6-8$ kbar with associated transpressive thrusting and tectonic imbrication. Geochronology on zircon, pyroxene and garnet constrains the timing of peak metamorphism at 1.98 - $2.05 \mathrm{Ga}$. Diffusion modeling of $\mathrm{Fe}-\mathrm{Mg}$ exchange between biotite inclusions and host garnet yields (near metamorphic peak) cooling rates of 50 $100{ }^{\circ} \mathrm{C} / \mathrm{Ma}$, with petrological cooling rates being generally consistent with cooling rates determined from geochronology. Combining the retrograde P-T path with cooling rates suggests that after the metamorphic peak, large portions of the Imataca Complex were exhumed from 30 to $17 \mathrm{~km}$ at a rate of $7-2 \mathrm{~km} / \mathrm{Ma}$. After this, exhumation rates progressively decreased as the rocks approached the surface. Rapid overall upliftlerosion had ceased when the rocks passed below $600-550{ }^{\circ} \mathrm{C}$ at $2.01-1.96 \mathrm{Ga}$ ago. Observed variations in mineral cooling ages are interpreted as to reflect episodic differential tectonic exhumation within major fault systems. Inferred (maximum) ages of fault re-activation generally coincide with major continental accretion events in the Amazonian Craton and reflect long-term thermal evolution of the Imataca terrane, as conditioned by variable response to continued continental convergence during the Proterozoic.

\section{Introduction}

High-grade (granulite facies) metamorphic rocks formed during ancient orogenic events yield information on early continental crust formation processes and therefore constitute important indicators of the long-term chemical and thermal evolution of the Earth (e.g., Fyfe, 1978; Ben Othman and Allégre, 1984; Richter, 1984). Moreover, in recent years it has become increasingly recognized that the pressure-temperature-time (P-T-t) paths deciphered from mineral assemblages in such rocks provide important constraints on geophysical and tectonic models of lower crust deformation, uplift and subsequent erosion (e.g., England and Richardson, 1980; England and Thompson, 1984; Bohlen, 1987). Application of tectonic models to the evolution of metamorphosed lower crust not only requires information on protolith (nature-age) characteristics (e.g., DePaolo et al., 1991), but also relies on a detailed understanding of the cooling rates of granulitic rocks. Indeed, the derived cooling patterns are essential to characterize the exhumation processes (uplift and/or erosion) that brought the rocks towards the surface (e.g. England and Molnar, 1990). Most cooling data on metamorphic terranes has been obtained through radiometric dating ("geochronological cooling rates"; Spear and Parrish, 1996) of different minerals with appropriate isotope closure temperatures (e.g., Cliff, 1985). Cooling rates can also be determined from analyses of diffusional zoning in metamorphic minerals ("petrological cooling rates"; Spear and Parrish, 1996). However, except for Spear and Parrish (1996) research on the $\leq 80$ Ma "old" Valhalla Metamorphic Complex (British Columbia, Canada), few systematic studies have been published comparing petrological and geochronological cooling rates. As cautioned by Spear and Parrish (1996), such a comparison is of critical importance in order to better assess the internal consistency of both methods; furthermore, cooling rates determined by geochronological and petrological methods may provide complementary information and therefore it is useful to use both methods on thermochronological studies of metamorphic terranes.

In this study, results of sensitive high-resolution ion microprobe (SHRIMP) U/Pb-isotope measurements are presented for zircons from felsic to intermediate granulites from the San Felix-Upata area (Figure 1) in the La Encrucijada domain (Ascanio, 1985) of the Imataca Complex (Venezuela) provide a time framework for protolith formation and high-grade metamorphism. Petrological investigation of Imataca Complex samples is used to define the main fea- 

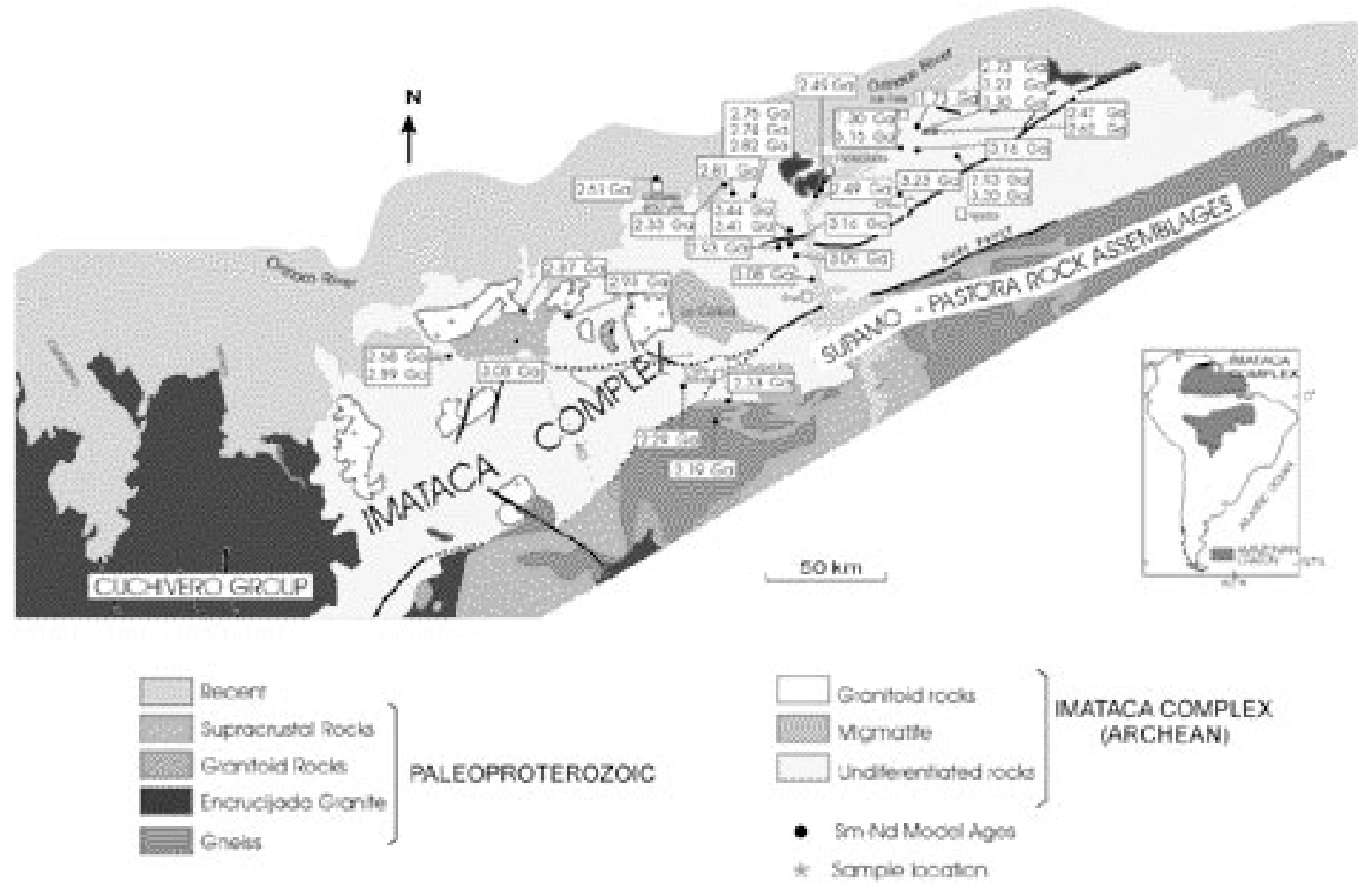

Figure 1 Simplified geological map of the Imataca Complex area, northwestern Amazonian Craton, with sample locations (Compiled from Win et al., 1993 and Teixeira et al., 2002).

tures of regional Transamazonian granulite metamorphism and the petrological cooling rates are inferred from diffusion modeling of $\mathrm{Fe}-\mathrm{Mg}$ exchange between biotite inclusions and their garnet hosts. The data are compared with new $\mathrm{Sm}-\mathrm{Nd}, \mathrm{Rb}-\mathrm{Sr}$ and previously reported ${ }^{40} \mathrm{Ar} /{ }^{39} \mathrm{Ar}$ (Onstott et al., 1988) mineral cooling ages in order to assess the thermochronology of the San Felix-Upata granulites of Imataca Complex, whereas Sm-Nd whole rock isotopic data are used to constraint the crustal residence ages and the composition of the protoliths in relationship with the mechanisms of crustal accretion. Finally, we discuss implications of our results for the geodynamic evolution of Imataca Complex.

\section{Geological setting}

The Archean Imataca Complex (Figure 1; Chase, 1965; Kalliokoski, 1965; Hurley et al., 1976) comprises the Venezuelan NW corner of the Amazonian Craton (Cordani and Brito Neves, 1982) and forms an ENE-trending, fault-bounded ( $\sim 500 \mathrm{~km}$ long) block, extending from below the northern Orinoco river floodplains to the Guri fault zone (Onstott and Hargraves, 1981), that separates the Complex from the Paleoproterozoic $(2.2-1.95 \mathrm{Ga})$ Supamo-Pastora granitegreenstone belt (Maroni-Itacaíunas Province) to the south (Figure 1; Tassinari and Macambira, 1999; Tassinari et al., 2000). The Imataca Complex consists predominantly of felsic, quartzo-feldspathic, granulites and variably migmatized ortho-/paragneisses (with local anatectic granitoids) that display (subordinate) compositionallyintergradational variations into intermediate/mafic compositions (gneisses, granulites). The paragneisses include minor interlayered dolomitic marbles and BIFs that constitute huge iron deposits of Algoma type. The main protolith of the Imataca Complex has been interpreted as representative of a differentiated calc-alkaline magmatic series (Dougan, 1977). However, except for granitic orthogneisses of clear igneous derivation, the lack of geochemical coherence among immobile element contents in mafic/intermediate lithotypes suggests that some (if not most) of these rocks represent metamorphosed chemical/clastic sediments that could have been derived from older granitic-basaltic (greenstone) sequences.

Imataca Complex rocks have been intensely deformed, metamorphosed and intruded by several granitic (e.g., La Encrucijada) plutons during the Transamazonian orogeny (Montgomery et al., 1978; Gibbs and Barron, 1983; Ascanio, 1985; Onstott et al., 1989; Swapp and Onstott, 1989). Metamorphic grade was at granulite facies over most of the northern areas of the Imataca Complex but changed to amphibolite facies towards the south, on approaching the Guri fault zone. Previous petrographic studies (Dougan, 1977) and our own field observations indicate that granulites south of Dougan's "pyroxene limit" have been extensively retrograded and transformed to amphibolites during superimposed cataclastic recrystallization; these features have regional expression, being observed for several kilometers along the main Guri ( $>1 \mathrm{~km}$ wide shear zone) and other (associated) fault zones (e.g., El Pao, Rio Claro; Ascanio, 1985), implying that the amphibolite/granulite transition in the Imataca Complex does not represent prograde metamorphism. All those major fault zones have been subsequently reactivated for several times (e.g., Gibbs and Barron, 1993) and they are of utmost significance on the tectonic framework of the Imataca Complex. Indeed, geological, palaeomagnetic and isotopic data (Onsttot and Hargraves, 1981; Tassinari and Macambira, 1999) indicate that the Guri fault zone corresponds to a major transamazonian continental suture, reflecting late-Paleoproterozoic accretion of the Imataca terrane into the proto-Amazonian Craton. During continental collision the Maroni-Itacaíunas terrane was thrust over the Imataca Complex (Ascanio, 1985), and the ensuing transpressive regime between these two terranes resulted in left lateral slip (Swapp and Onstott, 1989) with development of northward verging thrusts and complex imbrication within the Imataca Complex (Ascanio, 1985). The early stages of cooling and uplift of Imataca granulites may be related to thrusting along the major fault zones. 


\section{Analytical techniques}

Chemical mineral analyses were obtained by electron microprobe (Jeol Superprobe 733, Centro de Geologia FCUL, Portugal) analyses of polished, carbon-coated thin sections, using a combination of natural and synthetic standards; typical errors are less than $2 \%$ for major elements.

$\mathrm{Rb}-\mathrm{Sr}$ and $\mathrm{Sm}-\mathrm{Nd}$ isotopic analyses were carried out at the Centro de Pesquisas Geocronológicas (USP, Brazil). Standard analytical procedures were used for $\mathrm{Rb}-\mathrm{Sr}$ and $\mathrm{Sm}-\mathrm{Nd}$ analyses according to the methodology described by Tassinari et al. (2003) and Sato et al. (1995). Rb, Sr, Sm and Nd contents were measured by isotopic dilution techniques. Sr isotopic ratios were normalized to ${ }^{86} \mathrm{Sr} /{ }^{88} \mathrm{Sr}=$ 0.1194 and replicate analyses of ${ }^{87} \mathrm{Sr} /{ }^{86} \mathrm{Sr}$ for the NBS987 standard gave a mean value of $0.71028 \pm 0.00006(2 \sigma)$ with blank levels at 5 ng. $\mathrm{Nd}$ ratios were normalized to a ${ }^{146} \mathrm{Nd} /{ }^{144} \mathrm{Nd}=0.72190$ and the average of ${ }^{143} \mathrm{Nd} /{ }^{144} \mathrm{Nd}$ for La Jolla and BCR-1 standards were $0.511847 \pm 0.00005(2 \sigma)$ and $0.512662 \pm 0.00005(2 \sigma)$ respectively; blanks levels were less than $0.03 \mathrm{ng}$ during the period of analysis. $\mathrm{Sr}$ and $\mathrm{Nd}$ isotopic data were obtained on a multi-collector VG 354 Micromass mass spectrometer.

Zircon $\mathrm{U} / \mathrm{Pb}$ isotopic data were obtained from the Australian National University SHRIMP I instrument, using a $\sim 30 \mu$ m diameter spot. Stern (1998) and Williams (1998) describe calibration methods and analytical procedures. ${ }^{206} \mathrm{~Pb} /{ }^{238} \mathrm{U}$ ratios have an error component (typically 1.5 to $2.0 \%$ ) from calibration measurements using the standard zircons. U abundance was calibrated against $238 \mathrm{ppm} \mathrm{U}(<$ $\pm 10 \%$ ) fragments of the single crystal SL 13 standard and $\mathrm{Pb} / \mathrm{U}$ was calibrated against the multi-crystal standard AS57 (1100 Ma; Paces and Miller, 1993). All errors take into account non-linear fluctuations in ion counting rates beyond that expected from counting statistics (e.g. Stern, 1998). Age calculations were performed using the Ludwig (1998) ISOPLOT/Ex program.

\section{Sample descriptions}

Studied samples were collected from road cuttings and from an abandoned quarry near the village of San Félix (on the highway to Upata; see Figure 1). Within the collection area, the general strike of metamorphic foliation is close to E-W (steeply dipping to $S$ ) and predates the development of NE-SW shear zones that represent local expressions of the main (e.g., Guri, El Pao) regional faults. Typical bluish-quartz, garnet-orthopyroxene, and two-pyroxene bearing granulites are exposed in the sampling area, of which samples V1 to V8 are representative. Sample V9 is a felsic (quartzo-feldspathic) segregation in garnet-granulites (selected for zircon geochronology). Finally, sample V10 is a quartz + plagioclase + K-feldspar + biotite \pm muscovite "blastomylonite" collected from a shear zone. It has a planar fabric defined by aligned biotite and quartz plus feldspars that have experienced deformation and grain size reduction.

The metamorphic history of granulites is best reflected in samples V-6, V-7 and V-8; a summary description of the petrography, mineral-chemistry and thermobarometric investigation of these samples is given below.

\section{Metamorphism}

Granulites of the Imataca Complex were previously described by Dougan (1974) and Swapp and Onstott (1989).

Of the three samples selected for this petrologic study, two (V6, V7) are garnet + orthopyroxene + plagioclase + K-feldspar + biotite + quartz bearing granulites and V8 is a two-pyroxene + plagioclase + K-feldspar + hornblende + biotite + quartz granulite .

Granulite V8 has typical granuloblastic texture and relatively homogeneous mineral compositions. Pyroxenes have very small amounts of non-quadrilateral components and display slight core to rim $\mathrm{Fe} / \mathrm{Mg}$ zoning (cpx: $0.66 \rightarrow 0.64$; opx: $1.23 \rightarrow 1.27$ ). Other FeMg minerals do not display detectable zoning; orthopyroxene (opx), clinopyroxene (cpx), amphibole (hb) and biotite (bio) have (average) $\mathrm{Fe} / \mathrm{Mg}$ values ordered as follows: $\mathrm{opx}^{\mathrm{Fe} / \mathrm{Mg}}>\mathrm{hb}^{\mathrm{Fe} / \mathrm{Mg}=1.19}$ $>\mathrm{bio}^{\mathrm{Fe} / \mathrm{Mg}}=0.90>\mathrm{cpx}^{\mathrm{Fe} / \mathrm{Mg}}$. Amphiboles display extensive tschermak substitution $(\mathrm{Si} \sim 6.4, \mathrm{Al} \sim 2.0$ a.p.f.u.) and significant A-site occupancy $\left(\mathrm{K}^{\mathrm{A}}>0.32\right)$, indicating crystallization under high-temperature conditions. $X_{a n}$ in plagioclase ranges from 0.42 to 0.44 , whereas $\mathrm{X}_{\mathrm{ab}}$ in $\mathrm{K}$-feldspar is $\sim 0.1$.

Garnet granulites have granuloblastic texture, particularly well equilibrated in sample V6. Sample V7 has higher modal amounts of garnet and displays gneissic structure due to alternating garnet+ biotite- and feldspar-richer layers. Orthopyroxene and (particularly) garnet contain abundant biotite inclusions (especially, in sample V7) and larger orthopyroxene crystals surround (earlier) garnet, separating it from plagioclase. These features, coupled with complex plagioclase + K-feldspar intergrowths, suggest that the decompression P-T path followed by these rocks may have reached conditions that were close to those of biotite dehydration melting,

biotite + quartz $\rightarrow$ orthpyroxene + K-feldspar + liquid (1)

Garnet $\left(\mathrm{Alm}_{75-78} \mathrm{Py}_{9-13} \mathrm{Gr}_{9} \mathrm{Sps}_{3-4}\right)$ and orthopyroxene $\left(\mathrm{En}_{36-38}\right.$ $\mathrm{Fs}_{61-63} \mathrm{Wo5}_{5}$ ) compositional variations are dominated by almandine-pyrope and enstatite-ferrosilite solid solutions. Almandine/pyrope and enstatite/ferrosilite are zoned such that $\mathrm{Fe} / \mathrm{Mg}$ increases in garnet (V6: $6.25 \rightarrow 7.37 ; \mathrm{V7}: 5.90 \rightarrow 7.51$ ) and decreases in orthopyroxene (V6: Fe/Mg $=1.86 \rightarrow 1.67$; V7: $1.91 \rightarrow$ 1.83) from core to rim. Garnet zoning may be symmetrical about the rim, but it is also observed in garnet touching biotite and/or orthopyroxene (V6: $\mathrm{Fe} / \mathrm{Mg}^{\text {garnet }}=6.25 \rightarrow 8.68$ ), resulting from diffusion controlled Fe-Mg exchange on cooling (Spear and Florence, 1992). Detailed analyses of biotite inclusions in garnet also reveal that there is a correlation between biotite $\mathrm{Fe} / \mathrm{Mg}$ and biotite size (smaller biotite inclusions have lower Fe/Mg: V7: $60 \mu \mathrm{m}-\mathrm{Fe} / \mathrm{Mg}=0.89$; $250 \mu \mathrm{m}-\mathrm{Fe} / \mathrm{Mg}=1.35$ ). Biotite $\mathrm{Fe} / \mathrm{Mg}$ is also a function of the location in the sample, such that matrix biotites (away from garnet) generally have higher $\mathrm{Fe} / \mathrm{Mg}$ values than those of biotites included in garnet (V7: Fe/ $\left.\mathrm{Mg}_{\text {matrix bio }}=1.46-1.55\right)$. Some late stage biotites may have formed by retrograde operation (from left to right) of reac-

tion (1), but the small $K$ (see also, Spear and Markusen, 1997)

ensures that the early matrix biotites still provide reliable indicators of peak metamorphic conditions. All these features are consistent with the interpretation that the $\mathrm{Fe}-\mathrm{Mg}$ zoning in garnet, and biotite $\mathrm{Fe} / \mathrm{Mg}$ variations are products of diffusion in response to gradients caused by $\mathrm{Fe}-\mathrm{Mg}$ exchange between biotite+orthopyroxene and adjacent garnet (Spear and Parrish, 1996; biotite inclusion data will be used below to infer petrological cooling rates). Plagioclase is homogeneous within each sample $\left(\mathrm{X}_{\mathrm{an}}=0.23\right.$ in $\mathrm{V} 6, \mathrm{X}_{\mathrm{an}}=0.25$ in V7), whereas $X_{a b}$ in $\mathrm{K}$-feldspar ranges from 0.10 to 0.17 .

\section{Thermobarometry: Peak metamorphic conditions and P-T path}

Previous estimates of Transamazonian peak metamorphic conditions in the Imataca Complex have been reviewed by Swapp and Onstott (1989), who suggested $\mathrm{T}$ and $\mathrm{P}$ in the range of $750-800{ }^{\circ} \mathrm{C}$ and $8-8.5$ kbar for granulites at El Pao mine. Compositions of garnet, orthopyroxene, biotite and plagioclase coexisting with quartz in samples V6 and V7 provide useful constraints on metamorphic conditions at San Felix. Calculations based on the TWQ approach (Berman, 1988; 1991; Berman and Aranovich, 1996) yield peak (core) temperature and pressure estimates at $740 \pm 20{ }^{\circ} \mathrm{C}, 6.7 \pm 0.4$ kbar for sample V7. TWQ geothermobarometric results agree with those obtained from several other methods $\left(\mathrm{T}_{\text {garnet-matrix biotite }}=724\right.$ $-774{ }^{\circ} \mathrm{C}$ : Hodges and Spear, 1982; $\mathrm{T}_{\text {garnet-orthopyroxene }}=747-$ 
$787^{\circ} \mathrm{C}$ : Lee and Ganguly, $1988 ; \mathrm{T}=786 \pm 93{ }^{\circ} \mathrm{C}, \mathrm{P}=6.7 \pm 1.3 \mathrm{kbar}$ : Holland and Powell, 1998). These are also consistent with twopyroxene $\left(767 \pm 20^{\circ} \mathrm{C}\right.$ : Andersen et al., 1993) and hornblende-plagioclase $\left(770 \pm 40{ }^{\circ} \mathrm{C}\right.$ : Holland and Blundy, 1994) geothermometry on sample V8 (two-pyroxene granulite) from a nearby outcrop. Swapp and Onstott (1989) mineral data for garnet granulite sample IM115, recalculated according to the TWQ geothermobarometric method, yield $814 \pm 20^{\circ} \mathrm{C}$ and $7.7 \pm 0.4$ kbar. This suggests either that peak T-P metamorphic conditions were slightly higher at El Pao mine, or that San Felix granulites were re-equilibrated at lower than peak conditions. Geothermobarometric data from sample V6 support the re-equilibration hypothesis; estimated core to rim $\mathrm{T}$ and $\mathrm{P}$ conditions decrease from $660 \pm 40^{\circ} \mathrm{C}$ to $570 \pm 20^{\circ} \mathrm{C}$ and $5.9 \pm 0.8 \mathrm{kbar}$ to $4.2 \pm 0.4$, indicating that extensive recrystallization proceeded with decreasing temperature and pressure. Thus, overall data suggest that San Felix granulites reached peak metamorphic conditions at $750-$ $800{ }^{\circ} \mathrm{C}, 6-8 \mathrm{kbar}$, followed by decompression and cooling.

Figure 2 summarizes the P-T path constraints based on pertinent reaction equilibria. Petrographic evidence to constrain the prograde P-T evolution of San Felix granulites has been mostly erased by subsequent reactions. However, our data are consistent with that of Swapp and Onstott (1989) and both suggest a clockwise P-T path involving decompression and heating to peak conditions, with the general absence of early kyanite in the Imataca rocks (Dougan, 1974; Swapp and Onstott, 1989) limiting the amount of decompression to $<2$ kbar. A constraint on the retrograde P-T path comes from noting that $3 \mathrm{qz}+\mathrm{gr}+2 \mathrm{alm}=6 \mathrm{fs}+3 \mathrm{an}$ equilibrium (Berman and Aranovich, 1996) has an almost constant slope for the investigated compositions. Therefore, the retrograde path (Figure 2) was tentatively draw to follow that line down to about $600{ }^{\circ} \mathrm{C}$, at $\sim 13$ bars/degree ${ }^{\circ} \mathrm{C}$. Assuming a linear pressure gradient with depth and a constant rock column density of $2.7 \mathrm{~g} . \mathrm{cm}^{-3}$, the retrograde path corresponds to a temperature-depth gradient of $20^{\circ} \mathrm{C} / \mathrm{km}$. Extrapo-

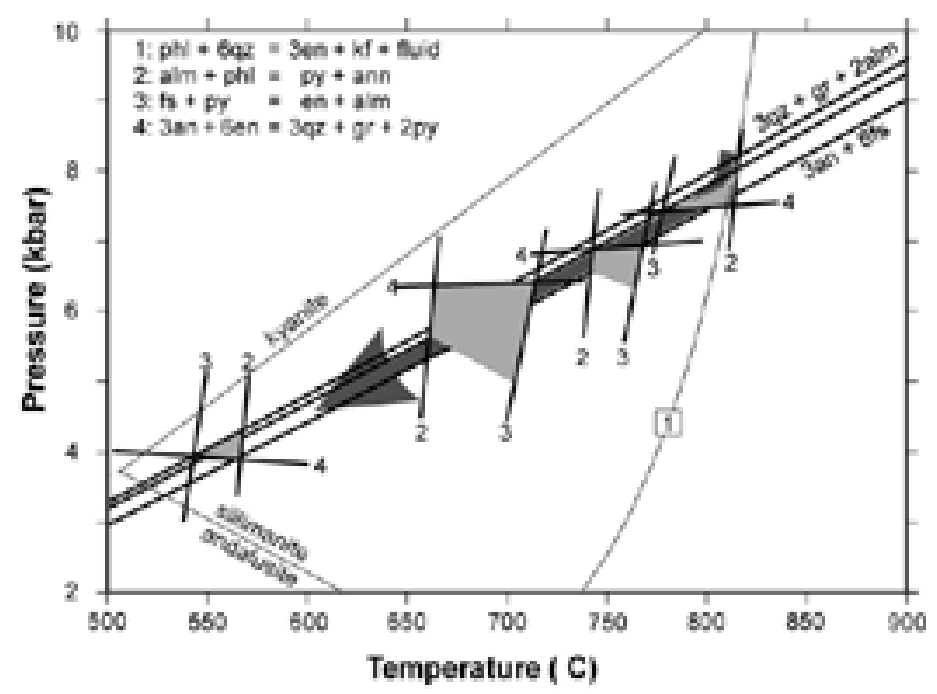

Figure 2 Pressure and temperature constraints for the Imataca Complex granulites. Displayed reaction equilibria calculated according to Berman (1988) and Berman and Aranovich (1996) thermodynamic data. "Arrow" illustrates the retrograde path as discussed in text.

lation of this path to the surface results in unreasonable hot surfaces temperatures $\left(>200^{\circ} \mathrm{C}\right)$, indicating that geothermal gradients must have increased (to $>30-40{ }^{\circ} \mathrm{C} / \mathrm{km}$ ) as the rocks were exhumed to the surface (e.g., England and Thompson, 1984). Regardless of the actual meaning of the estimated retrograde P-T path, it is worth noting that the San Felix granulites must have remained at relatively high temperatures for long enough to allow the observed retrograde re-equilibration.

\section{Petrological cooling rates}

The theory and methods that use chemical zoning in minerals to infer cooling rates have been discussed at length by a large number of workers (e.g. Dodson, 1973, 1986; Lasaga, 1983; Wilson and Smith, 1984; Spear, 1991; Spear and Parrish, 1996); therefore, only a brief summary is be provided here. The method follows the technique developed by Spear and Parrish (1996). Their approach provides a simple (but rigorous) characterization of the reaction framework that governs compositional boundary conditions, restricting the diffusion model analyses to $\mathrm{Fe}-\mathrm{Mg}$ exchange between host garnet and biotite inclusions in order to assess cooling rates. It is assumed that $\mathrm{Fe}-\mathrm{Mg}$ inter-diffusion is induced by compositional variations at garnet-biotite interfaces in response to changing $\mathrm{KD}(\mathrm{Mg} / \mathrm{Fe})^{g t-b i o}$ values during the cooling process. As temperature decreases garnet becomes enriched in $\mathrm{Fe} / \mathrm{Mg}$ and biotite becomes depleted, until, at sufficiently low temperature $\left(T_{c}=\right.$ closure temperature), the process effectively ceases. Considering mass balance requirements (the diffusive flux out of garnet must be matched by the diffusive flux into biotite), and noting that the diffusion process is

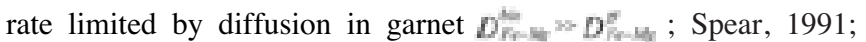

Spear and Parrish, 1996), the Fe/Mg variations in biotite will be a function of the size of the biotite inclusions (smaller inclusions will change composition more than larger ones). The composition of each biotite inclusion can therefore be transformed into its respective closure temperature (by using the garnet core composition). Thus in each case, $T_{c}=f$ (biotite size ) reflects the total diffusive flux out of garnet (Spear and Parrish, 1996), reflecting the thermochronological history (see, Dodson, 1973). The corresponding cooling rates are then obtained by comparison of biotite inclusion Tc data with the results of (computer) model diffusion calculations performed under known conditions.

In this study, initial conditions for the diffusion algorithm assume homogeneous biotite and garnet (of appropriate sizes and compositions) at the estimated peak T-P metamorphic conditions ( $T_{0}$ $=800{ }^{\circ} \mathrm{C}, \mathrm{P}=7 \mathrm{kbar}$ ). As cooling proceeds, garnet-biotite interface compositions will change (as prescribed by the simulated thermal

history, $\quad T^{\circ} C=g(t-M a)$ in accordance to $K^{D-x_{0}}-h(T(t))$ (Ferry and Spear, 1978) and solution of the diffusion equation

$$
\frac{\partial C}{\partial T}-D_{N-3 x^{*}}^{*} \frac{\partial^{2} C}{\partial r^{2}}
$$

(Crank, 1975), is approximated by a finite difference model (diffusion in spherical $\rightarrow$ garnet and cylindrical $\rightarrow$ biotite geometries), using

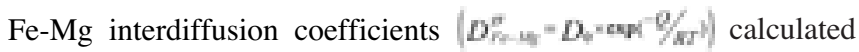

according to Lasaga (1979) from Chakraborty and Ganguly (1992; see also Ganguly et al., 1998) experimental data.

Figure 3 displays a comparison between observed $T_{c}-\log$ (biotite diameter) relations for San Felix garnet-granulite samples and the results obtained from the computational simulation of garnet-biotite $\mathrm{Fe}-\mathrm{Mg}$ diffusion exchange. As it should be expected, there is a broad correlation between inclusion biotite size $(30-250$ $\mu \mathrm{m})$ and garnet-biotite closure temperatures $\left(550-720^{\circ} \mathrm{C}\right)$. It can be seen that the San Felix $T_{c}-\log$ (biotite diameter) variation trend has a considerably higher slope than that of any line depicting modeled constant cooling rates in Figure 3; thus, a straightforward comparison with those model results is not justified. A feasible explanation for the data is that the retrograde P-T path of San Felix granulites proceeded under decreasing cooling rates.

Because of initial fast cooling, rapidly decreasing diffusive fluxes out of garnet will soon become unable to cope with compositional variations at the interfaces with the largest biotite crystals and these inclusions will partially close to exchange early in the cooling process. During subsequent cooling, larger biotites will behave like 


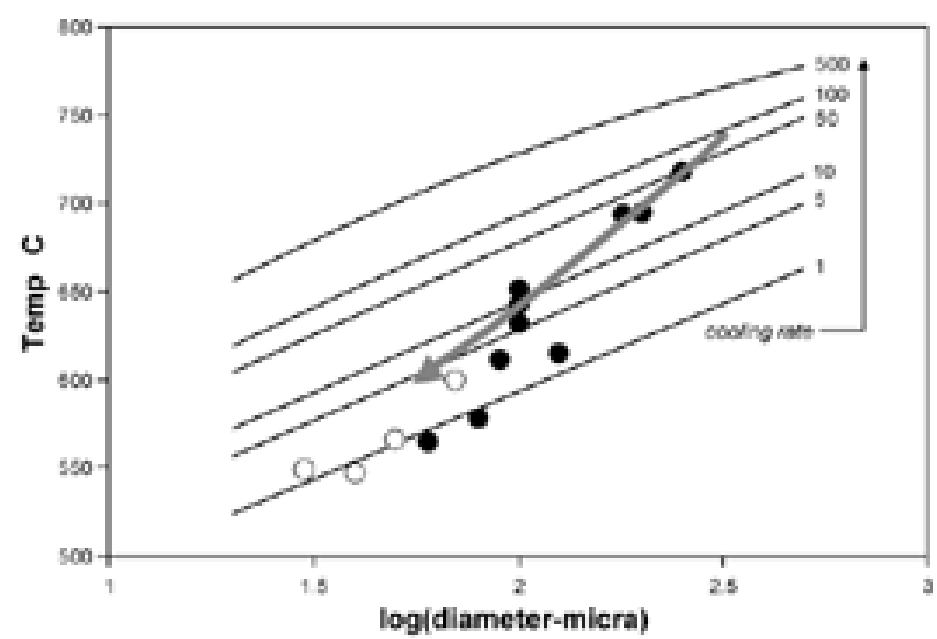

Figure 3 Plot of closure temperatures, calculated from garnet (core)-biotite (inclusion) thermometry (Hodges and Spear, 1982), vs. biotite size (log diameter-(m) for San Felix granulites (circumferences: V6; filled circles: V7). Continuous thin lines are model results for constant cooling rates and thick arrow is model result for decreasing cooling rates, as discussed in text.

minerals with limited extent of diffusion (Ganguly and Tirone, 1999), becoming less susceptible than the smaller ones to further compositional adjustments that result from later decrease in cooling rates at lower temperatures. Therefore, $T_{c}-\log$ (biotite diameter) variation trends characteristic of decreasing cooling rate thermal regimes will be steeper than those depicting constant cooling rates. Following this reasoning, a wide variety of thermal histories have been explored by diffusion modeling. These numerical experiments indicate that the garnet-biotite (inclusion) data can be reasonably explained if the San Felix granulites cooled at a rate approaching 50 $-100{ }^{\circ} \mathrm{C} / \mathrm{Ma}$ over the first $150{ }^{\circ} \mathrm{C}\left(800-650^{\circ} \mathrm{C}\right)$, followed by much slower cooling $\left(10-1^{\circ} \mathrm{C} / \mathrm{ma}\right)$, as indicated in Figure 3 .

\section{Geochronology}

Thirty two new results of $\mathrm{U} / \mathrm{Pb}$ and $\mathrm{Sm} / \mathrm{Nd}, \mathrm{Rb} / \mathrm{Sr}$ isotopic analyses on whole rock and mineral (zircon, garnet, pyroxene, biotite and feldspar) separates from the Imataca Complex have been obtained during this study (Tables I and II). We will first address SHRIMP $\mathrm{U} / \mathrm{Pb}$-zircon and $\mathrm{Sm} / \mathrm{Nd}$ whole rock data in order to unravel protolith ages and crustal residence times. We will then describe mineral ages that are pertinent on the thermochronological characterization of Imataca granulites.

\section{Protolith ages}

Previous $\mathrm{Rb} / \mathrm{Sr}$ and $\mathrm{Pb} / \mathrm{Pb}$ whole rock analyses on the Imataca Complex (Hurley et al., 1972, 1973, 1976; Montgomery and Hurley, 1978; Montgomery, 1979) suggest that protolith ages go back to at least $3.1 \mathrm{Ga}$ and might be as old as $3.4-3.7 \mathrm{Ga}$. Also, early highgrade metamorphic reworking (La Ceiba migmatites; Figure 1) could have taken place at about $2.8 \mathrm{Ga}$ ago (Teixeira et. al., 1989).

Mineral separates from garnet-granulite V6 and felsic segregation V9 yielded predominantly prismatic zircons, showing, (through cathodoluminescence imagery) fine scale oscillatory zoning and homogeneous (rim) overgrowths. Oscillatory-zoned zircon of this type is interpreted as to have grown out of felsic magmas (Pidgeon et al., 1998). Our study of nine analyses focused on zircon sites with well preserved zoning (typical of magmatic zircon). The purpose of this reconnaissance-style work was not to provide precise ages on any event, but to give indications of timing of high temperature geological events from the $\mathrm{U} / \mathrm{Pb}$ zircon perspective, to be integrated with $\mathrm{Sm}-\mathrm{Nd}$ and $\mathrm{Rb}-\mathrm{Sr}$ data. SHRIMP U/Pb-zircon isotopic data are plotted on a ${ }^{207} \mathrm{~Pb} / 206 \mathrm{~Pb}-{ }^{238} \mathrm{U} / 206 \mathrm{~Pb}$ diagram in Figure 4. Reported ${ }^{204} \mathrm{~Pb} / 206 \mathrm{~Pb}$ ratios (Table I) are below 0.0004 , which gives a maximum $206 \mathrm{~Pb}_{\text {non-radiogenic }} / 206 \mathrm{~Pb}_{\text {total }}=0.50 \%$, and only minor corrections for common lead. Except for spot analyses V9/1.1, zircon cores are not strongly discordant. Zircon sites of well-preserved oscillatory-zoning (apart from V6-1.1 displaying recrystallization) from the middle and ends of the grains from sample V6 yielded

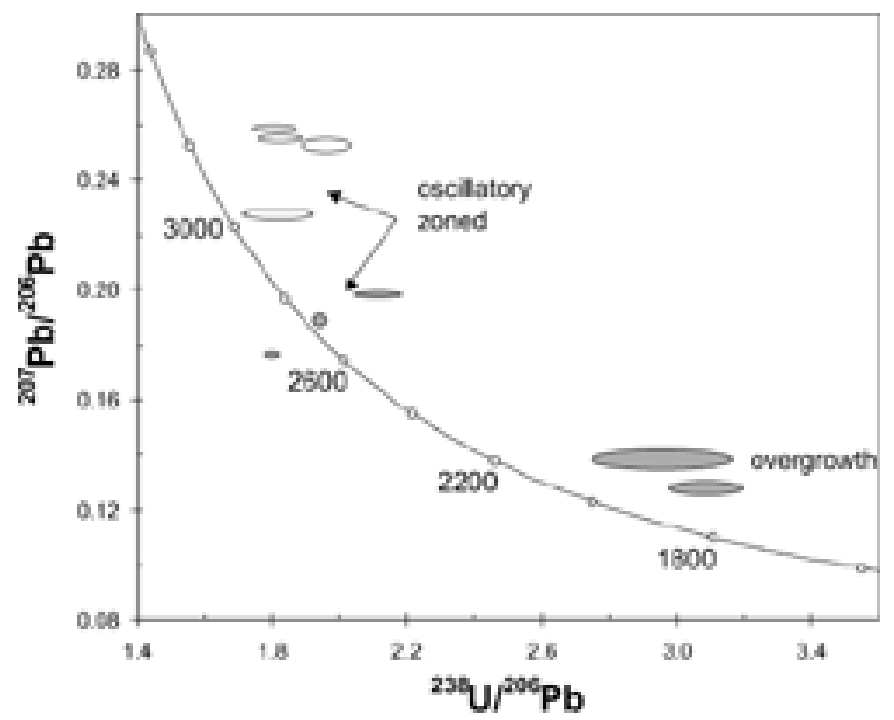

Figure 4 SHRIMP ${ }^{238} \mathrm{U}^{206} \mathrm{~Pb}-{ }^{207} \mathrm{~Pb} /{ }^{206} \mathrm{~Pb}$ Tera-Wasserbourg diagram for zircons from San Felix-Upata samples, V6 (filled symbols) and V9 (open symbols).

Table I Zircon SHRIMP data

\begin{tabular}{|c|c|c|c|c|c|c|c|c|c|c|c|c|}
\hline sample & grain type & $\begin{array}{l}\mathrm{U} \\
\mathrm{ppm}\end{array}$ & $\begin{array}{l}\text { Th } \\
\text { ppm }\end{array}$ & $\mathrm{Th} / \mathrm{U}$ & $\mathrm{Pb}^{*}$ & $\begin{array}{l}204 \\
\text { ppb }\end{array}$ & $238 / 206$ & $1 \sigma$ & $207 / 206$ & $1 \sigma$ & $\begin{array}{l}\text { age } \\
07 / 206 \mathrm{Ma}\end{array}$ & $1 \sigma$ \\
\hline V6-1.1 & $\mathrm{m}, \mathrm{osc} / \mathrm{hb}, \mathrm{p}$ & 343 & 125 & 0.37 & 210 & 9 & 1.7989 & 0.0123 & 0.1774 & 0.0005 & 2629 & 5 \\
\hline V6-4.1 & e,osc,p & 327 & 92 & 0.28 & 184 & 2 & 1.9408 & 0.0154 & 0.1896 & 0.0016 & 2739 & 14 \\
\hline V6-5.1 & $\mathrm{r}, \mathrm{h}, \mathrm{p}$ & 219 & 96 & 0.44 & 81 & 24 & 2.9552 & 0.1730 & 0.1390 & 0.0030 & 2215 & 37 \\
\hline V6-6.1 & $\mathrm{c}, \mathrm{osc}, \mathrm{anh}$ & 339 & 150 & 0.44 & 181 & 8 & 2.1163 & 0.0594 & 0.1988 & 0.0008 & 2816 & 7 \\
\hline V6-7.1 & $\mathrm{r}, \mathrm{h}, \mathrm{anh} / \mathrm{p}$ & 137 & 135 & 0.99 & 54 & 12 & 3.0979 & 0.0938 & 0.1269 & 0.0020 & 2055 & 28 \\
\hline V9-1.1 & $\mathrm{e}, \mathrm{osc}, \mathrm{p}$ & 163 & 102 & 0.63 & 102 & 3 & 1.9605 & 0.0588 & 0.2528 & 0.0020 & 3203 & 12 \\
\hline V9-2.1 & $\mathrm{m}, \mathrm{osc}, \mathrm{p}$ & 89 & 52 & 0.58 & 60 & 7 & 1.8205 & 0.0534 & 0.2556 & 0.0011 & 3220 & 7 \\
\hline V9-3.1 & $\mathrm{m}, \mathrm{osc}, \mathrm{p}$ & 487 & 126 & 0.26 & 299 & 14 & 1.8167 & 0.0858 & 0.2277 & 0.0013 & 3036 & 9 \\
\hline V9-4.1 & $\mathrm{m}, \mathrm{osc}, \mathrm{p}$ & 156 & 78 & 0.50 & 103 & 2 & 1.8069 & 0.0518 & 0.2589 & 0.0009 & 3240 & 5 \\
\hline
\end{tabular}

anh-anhedral; c-core; e-end; h-homogeneous; m-middle; osc-fine scale zoning; p- prismatic; r-overgrowth. 
Table II Sm-Nd and Rb-Sr data

\begin{tabular}{|c|c|c|c|c|c|c|c|c|c|c|c|}
\hline samp. & mat.(1) & $\mathrm{Sm}$ & $\mathrm{Nd}$ & $\begin{array}{l}{ }^{147} \mathrm{Sm} / \\
{ }^{144} \mathrm{Nd}\end{array}$ & $2 \sigma$ & $\begin{array}{l}{ }^{143} \mathrm{Nd} / \\
{ }^{144} \mathrm{Nd}\end{array}$ & $2 \sigma$ & $\begin{array}{l}\text { Mineral } \\
\text { Ages Ma (2) }\end{array}$ & $\begin{array}{c}(143 / 144) \\
(2 \mathrm{Ga})\end{array}$ & ${ }_{0} \varepsilon_{\mathrm{N}} \delta(2 \mathrm{Ga})$ & $\begin{array}{c}\mathrm{T}_{(\mathrm{DM})} \\
\mathrm{Ga}\end{array}$ \\
\hline V6 & $\mathrm{gt}$ & 6.676 & 5.237 & 0.7709 & 0.0031 & 0.519748 & 0.000013 & $2009 \pm 11$ & & & \\
\hline V7 & gt & 7.951 & 6.829 & 0.7040 & 0.0026 & 0.518548 & 0.000048 & $1896 \pm 17$ & & & \\
\hline$\overline{\mathrm{V} 8}$ & $\mathrm{px}$ & 4.025 & 12.457 & 0.1954 & 0.0007 & 0.512348 & 0.000015 & $1976 \pm 49$ & & & \\
\hline $\mathrm{V}-1$ & $\mathrm{wr}$ & 4.947 & 20.291 & 0.1474 & 0.0005 & 0.511575 & 0.000012 & & 0.509634 & -8.1 & 2.89 \\
\hline $\mathrm{V}-2$ & wr & 13.300 & 101.650 & 0.0791 & 0.0003 & 0.510654 & 0.000011 & & $0.509613-$ & 8.5 & 2.92 \\
\hline V-3 & $\mathrm{wr}$ & 2.659 & 10.664 & 0.1508 & 0.0005 & 0.511705 & 0.000030 & & $0.509720-$ & 6.4 & 2.77 \\
\hline V-4 & $\mathrm{wr}$ & 19.602 & 107.531 & 0.1102 & 0.0004 & 0.511218 & 0.000013 & & 0.509767 & -5.5 & 2.70 \\
\hline V-5 & wr & 4.705 & 18.802 & 0.1513 & 0.0005 & 0.511778 & 0.000011 & & 0.509786 & -5.1 & 2.67 \\
\hline V-6 & wr & 5.517 & 17.732 & 0.1881 & 0.0006 & 0.512041 & 0.000010 & & $0.509565-$ & 9.4 & 2.98 \\
\hline V-7 & $\mathrm{wr}$ & 5.180 & 19.294 & 0.1623 & 0.0006 & 0.511789 & 0.000018 & & $0.509652-$ & 7.7 & 2.86 \\
\hline V-8 & wr & 1.744 & 8.914 & 0.1183 & 0.0004 & 0.511345 & 0.000018 & & $0.509788-$ & 5.1 & 2.67 \\
\hline sample & materia & & $\mathrm{Rb}$ & $\mathrm{Sr}$ & ${ }^{87} \mathrm{Rb} /{ }^{86} \mathrm{Sr}$ & $2 \sigma$ & ${ }^{87} \mathrm{Sr} /{ }^{86} \mathrm{Sr}$ & $2 \sigma$ & $\begin{array}{l}\text { Mineral Ages } \\
\mathrm{Ma}^{(2)}\end{array}$ & $\begin{array}{c}(87 \mathrm{Sr} / 86 \mathrm{Sr})_{0} \\
2 \mathrm{Ga}\end{array}$ & \\
\hline V6 & bio & & 614 & 13.37 & 198.928 & 1.621 & 5.789510 & 0.005280 & $1769 \pm 14$ & & \\
\hline V6 & $\mathrm{pl}+\mathrm{KF}$ & & 43.5 & 201 & 0.628 & 0.011 & 0.743428 & 0.000074 & & & \\
\hline V7 & bio & & 624 & 13.27 & 203.529 & 1.635 & 5.771100 & 0.005620 & $1724 \pm 14$ & & \\
\hline V7 & opx & & 3.56 & 8.90 & 1.162 & 0.009 & 0.751820 & 0.000060 & & & \\
\hline V10 & bio & & 1152 & 16.04 & 350.899 & 2.805 & 7.750270 & 0.001780 & $1389 \pm 11$ & & \\
\hline V10 & KF & & 171 & 135 & 3.701 & 0.030 & 0.835180 & 0.000033 & & & \\
\hline V10 & $\mathrm{wr}$ & & 273 & 151 & 5.317 & 0.049 & 0.867518 & 0.000078 & & & \\
\hline V6 & wr & & 38 & 183 & 0.603 & 0.005 & 0.744450 & 0.000130 & & 0.72709 & \\
\hline V7 & $\mathrm{wr}$ & & 184 & 284 & 1.887 & 0.007 & 0.775077 & 0.000132 & & 0.72072 & \\
\hline V8 & $\mathrm{KF}$ & & 9.2 & 454 & 0.057 & 0.003 & 0.711904 & 0.000057 & & 0.71026 & \\
\hline V8 & $\mathrm{px}$ & & & & & & 0.712279 & 0.000050 & & & \\
\hline
\end{tabular}

(1) - bio: biotite, KF: K-feldspar, gt: garnet, pl: plagioclase, opx: orthpyroxene, px: pyroxene, wr: whole rock

(2) - mineral - whole rock ages.

${ }^{207} \mathrm{~Pb} / 206 \mathrm{~Pb}$ ages of $2629( \pm 5)-2739( \pm 14) \mathrm{Ma}$, whereas a site from the core of grain V6/6 yielded the oldest age at $2816 \pm 7 \mathrm{Ma}$; this age is in close agreement with La Ceiba migmatite $\mathrm{Rb} / \mathrm{Sr}$ whole rock isochron at $2.78 \mathrm{Ga}$ (Hurley et al., 1973). These results suggest a period of high-grade metamorphism, extensive melting and migmatite injection in the Imataca Complex during the lateArchean. Zircon analyses from sample V9 were also of the dominant oscillatory-zoned (middle/end) grain sites. Three of these sites yielded a weighted mean ${ }^{207} \mathrm{~Pb} /{ }^{206} \mathrm{~Pb}$ age of $3229 \pm 39 \mathrm{Ma}$ (MSWD $=5.2$ ) and a fourth site yielded $3036 \pm 9$ Ma that might reflect partial lead loss during younger thermal event(s). The dates are consistent with a mid-Archean age $(\geq 3.2 \mathrm{Ga})$ for at least some Imataca protolith(s).

\section{Nd isotopic systematics}

The $\mathrm{Nd}$ (and $\mathrm{Sr}$ ) isotopic data are summarized in Table II. There is some debate as to whether high-grade metamorphic differentiation of continental crust may, or may not, involve fractionation of Sm and Nd (e.g., Ben Othman et al., 1984; Burton and O'Nions, 1992). ${ }^{147} \mathrm{Sm} /{ }^{144} \mathrm{Nd}$ ratio in the Imataca samples ranges from 0.08 to 0.19 , largely overlapping the typical range for felsic crust with an average ${ }^{147} \mathrm{Sm} /{ }^{144} \mathrm{Nd}$ ratio of $\sim 0.11$ (Taylor and McLennan, 1985). Nevertheless, Figure 5 suggests that there was significant $\mathrm{Nd}$ isotopic resetting during Transamazonian metamorphism (see also, Montgomery and Hurley, 1978). Accordingly, $\varepsilon_{\mathrm{Nd}(\mathrm{t})}(\mathrm{DePaolo}, 1988)$ values have been calculated for $2.0 \mathrm{Ga}$, the inferred time of peak granulite-facies metamorphism (see bellow), in order to minimize the effects of possible alteration of the $\mathrm{Sm} / \mathrm{Nd}$ ratio by metamorphism. The $\varepsilon_{\mathrm{Nd}(2 \mathrm{Ga})}$ values for Imataca granulites show a limited range from - 5.1 to -9.4 (average $-7.0 \pm 1.7$ ) and are inversely correlated with $\left({ }^{87} \mathrm{Sr} /{ }^{86} \mathrm{Sr}\right)_{(2 \mathrm{Ga})}=0.7103-0.7271$, being consistent with a previous long-term residence in LREE and $\mathrm{Rb} / \mathrm{Sr}$ enriched upper crustal reservoir(s). Nd model ages, which are actually crustal residence times (e.g., O'Nions et al., 1983; Arndt and Goldstein, 1987), were calculated by using the measured $\mathrm{Sm} / \mathrm{Nd}$ ratio for the isotopic evolution until $2 \mathrm{Ga}$ ago and then assuming a typical crustal ${ }^{147} \mathrm{Sm} /{ }^{144} \mathrm{Nd}$ ratio of 0.11 for calculation of the intersection of the sample evolution line and the depleted mantle evolution curve (e.g., Ben Othman et al., 1984; Liew and Hofman, 1988). The corresponding mean Nd crustal residence ages of $2.8 \pm 0.1 \mathrm{Ga}$ (Table II) strongly support the $\mathrm{U} / \mathrm{Pb}$-zircon isotopic data (see above), and all indicate that the lateArchean $(\sim 2.8 \mathrm{Ga})$ was a period of major crustal reworking in the Imataca terrane. Convergence between $\mathrm{Nd}$ model ages and $\mathrm{U} / \mathrm{Pb}$-zircon data suggests that this event does not only involved internal differentiation of the pre-existing crustal rocks, but that a large fraction of new mantle derived material must have been added to pre-existing continental crust (McCulloch and Wasserburg, 1978; Veizer and Jansen, 1979; Allègre and Ben Othman, 1980; O'Nions et al., 1983). Thus, the "proto"-Imataca $(\geq 3.2 \mathrm{Ga})$ continental block must have grown considerably at that time. From $\sim 2.8 \mathrm{Ga}$ to $\sim 2.2 \mathrm{Ga}$ the Imataca terrane appears to have undergone a period of relative tectonic quiescence, which did however involved insipient continental rifting (Tassinari et al., 2000), during the early passive stages of the Transamazonian orogenic cycle.

\section{Thermochronology of Imataca Transamazonian granulites (geochronological cooling rates)}

Previous thermochronological studies in Imataca granulites (Onstott et al., 1989) have been concerned mainly with argon cooling ages within the lower metamorphic temperature range of $\sim 550$ ${ }^{\circ} \mathrm{C}$ to $\sim 150{ }^{\circ} \mathrm{C}$. However, in high-grade rocks, such as granulites, only phases with extremely slow diffusivities for the isotopes of interest will be able to preserve ages that are close to the thermal peak during metamorphism. In the Imataca case the available phases with such characteristics are zircon $(\mathrm{U} / \mathrm{Pb}$; Heaman and Parrish, 1991; Cherniak et al., 1997) and pyroxene (Sm/Nd; Van Orman et 


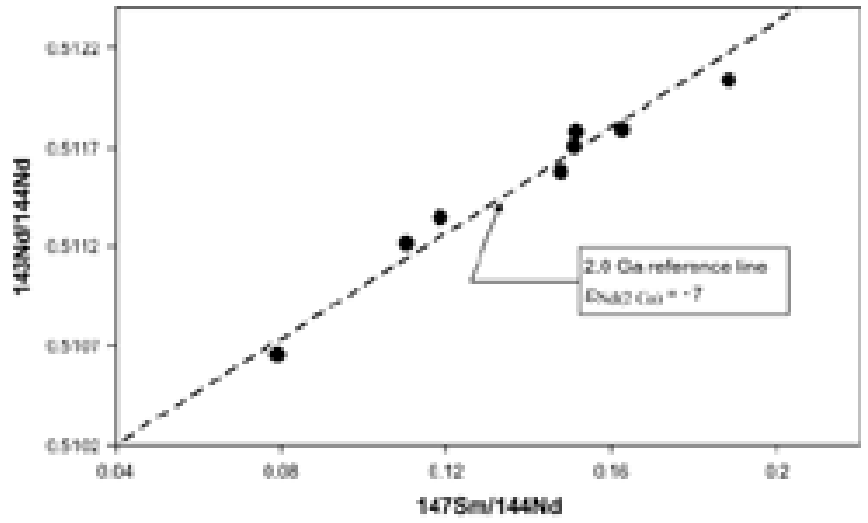

Figure 5 Plot of 147Sm/144Nd - 143Nd/144Nd relationships for whole-rock samples of San Felix-Upata granulites.

al., 2001). Thus the higher-temperature metamorphic and cooling chronology is described on the basis of U/Pb-zircon, $\mathrm{Sm} / \mathrm{Nd}$-pyroxene dating and the previously estimated petrological cooling rates. Moreover, new $\mathrm{Sm} / \mathrm{Nd}$-garnet and $\mathrm{Rb} / \mathrm{Sr}$-biotite mineral ages are presented to complement the Onstott et al., (1989) ${ }^{40} \mathrm{Ar} /{ }^{39} \mathrm{Ar}$ data.

$\mathrm{U} / \mathrm{Pb}$ - zircon and $\mathrm{Sm} / \mathrm{Nd}, \mathrm{Rb} / \mathrm{Sr}$ whole rock - mineral ages are summarized (together with isotopic data) in Tables I, II. ${ }^{40} \mathrm{Ar} /{ }^{39} \mathrm{Ar}$ closure temperatures discussed by Onstott et al. (1989) were generally adopted in this study (hornblende $\sim 550{ }^{\circ} \mathrm{C}$; biotite: $300{ }^{\circ} \mathrm{C}$; K-feldspar $\sim 400-150{ }^{\circ} \mathrm{C}$ ). In addition, closure temperatures of $600{ }^{\circ} \mathrm{C}$ for garnet $\left(\mathrm{Sm} / \mathrm{Nd}\right.$; Mezger et al., 1992) and $350{ }^{\circ} \mathrm{C}$ for biotite $(\mathrm{Rb} / \mathrm{Sr}$; Harrison and MacDougall, 1980) were assumed.

Two reconnaissance analyses of relatively homogeneous overgrowths on oscillatory-zoned zircon grains from sample V6 (sites 5.1 and 7.1 ; Table I) yielded $207 \mathrm{~Pb} / 206 \mathrm{~Pb}$ ages of $2215 \pm 37$ and $2055 \pm 28 \mathrm{Ma}$. The thin metamorphic overgrowths and (apparent) 'zoned cores' are extremely difficult to separate with the SHRIMP $30 \mu \mathrm{m}$ size spot and may give composite zircon ages, which are intermediate between the values of the respective cores and metamorphic grains. The site with the least discordant, younger date seems most free of core material and is interpreted as the closest indication the metamorphic peak age. This date, taken together with the $1976 \pm 49 \mathrm{Ma} \mathrm{Sm} / \mathrm{Nd}$ pyroxene age (Table II) and Montgomery and Hurley (1978) Rb/Sr thin-slab whole-rock data $(\sim 2.02 \mathrm{Ga})$, give a coherent picture of the chronology of metamorphism, and indicate that the thermal peak was reached at $\sim 2.0 \mathrm{Ga}$ ago. Nevertheless, the beginning of high-grade metamorphism may have begun somewhat earlier, being induced by pervasive plutonic magmatism in the Imataca Complex at 2.28 - 2.09 Ga (Posadas and Kalliokoski, 1967).

The cooling history can be assessed using the age determinations of minerals that were open systems and subsequently passed through their closure temperatures during cooling. In Figure 6, these closure temperatures are plotted against the cooling ages of garnet, hornblende, biotite and K-feldspar. As seen in Figure 6, the detailed thermal history of the Imataca metamorphic rocks is highly complex. Notwithstanding this, a major trend is apparent, and indicates initial fast cooling followed by slower cooling rates of $1-2{ }^{\circ} \mathrm{C} / \mathrm{Ma}$, from $\sim 600{ }^{\circ} \mathrm{C}$ to $\sim 350{ }^{\circ} \mathrm{C}$. Petrologic cooling rates calculated near the metamorphic peak, are much higher and are in the range of 50-100 CC/Ma. Comparison of Figures 3 and 5 do indeed suggests that there is general agreement between the cooling rates obtained from garnet-biotite diffusion modeling and those obtained by thermochronology. Our data generally support Swapp and Onstott (1989) forward heat flow model for Imataca Complex. Thus, combining the model retrograde P-T path (see Figure 2) with the estimated cooling rates (Figs. 3 and 6), suggest that after peak metamorphism large portions of the Imataca terrane were exhumed from 30 to $17 \mathrm{~km}$ at a rate of 7 $-2 \mathrm{~km} / \mathrm{Ma}$ after which exhumation rates progressively decreased (e.g., $15 \rightarrow 10 \mathrm{~km}$ at a rate of $0.06-0.03 \mathrm{~km} / \mathrm{Ma}$ ) as the rocks approached the surface. Rapid uplift/erosion had ceased before the rocks passed below $600-550{ }^{\circ} \mathrm{C}(2.01-1.96 \mathrm{Ga}$ ago $)$, and the

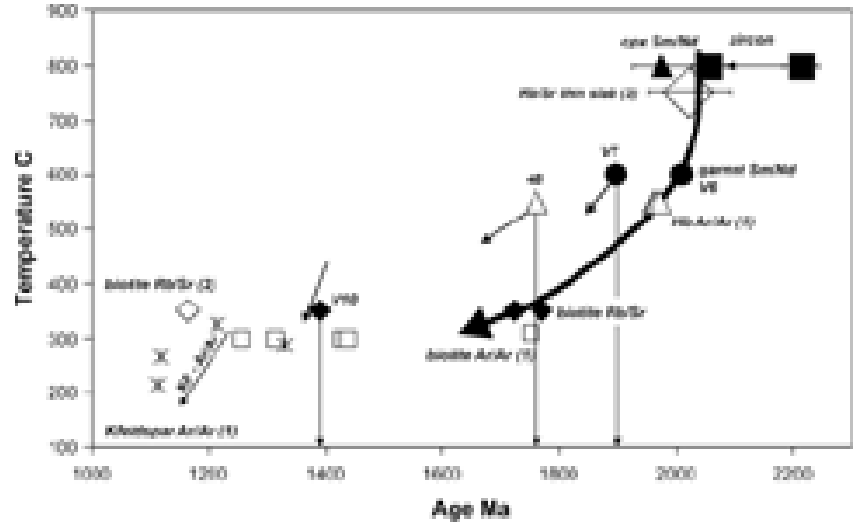

Figure 6 Plot of temperature vs. time for thermal history of Imataca granulites, based on mineral ages reported in Table II (filled symbols) and (1) - Onstott et al., (1989), (2) - Montgomery et al., (1977), (3) - Montgomery and Hurley (1978). Continuous (arrowed) thick line shows the main cooling trend for Imataca granulites. Inferred (maximum) ages of shear-zone re-activation in the Imataca Complex are illustrated by vertical thin (arrowed) lines (see text).

remaining Temperature - time trend shown in Figure 6 reflects thermo-mechanical recovery of the thinned crust on approaching isostatic equilibrium.

Despite the overall cooling trend, it is obvious from Figure 6 that large variations in cooling age occur between identical minerals (and isotopic systems) from neighboring areas in the Imataca Complex. The banded garnet-granulite sample V7 must have cooled below the garnet $\mathrm{Sm} / \mathrm{Nd}$ closure temperature $\left(\sim 600{ }^{\circ} \mathrm{C}\right)$ about 100 Ma later ( $1900 \mathrm{Ma}$; Table II) than the adjacent isotropic San Felix granulites. The amphibolite sample 48 (Onstott et al., 1989) from the La Ceiba migmatites (see Figure 1) yields a hornblende ${ }^{40} \mathrm{Ar} /{ }^{39} \mathrm{Ar}$ cooling age (1760 Ma) that is $\sim 200$ Ma younger than those of well preserved two-pyroxene granulites (1960 Ma; Onstott et al., 1989). An even more dramatic age range is provided by biotite $\mathrm{Rb} / \mathrm{Sr}$ cooling ages, with biotites from San Felix (sample V10; Table II) and Guri Dam (Montgomery et al., 1977; see Figure 1) shear zones yielding $1389 \mathrm{Ma}$ and $1165 \mathrm{Ma}$, respectively, $\sim 350$ to $600 \mathrm{Ma}$ younger than the remaining biotites $(1724-1769 \mathrm{Ma}$; Table II). Accepting the retrograde path $\left(\leq 600^{\circ} \mathrm{C}\right)$ of $30^{\circ} \mathrm{C} / \mathrm{km}$ (as discussed above) and a constant cooling rate of $\sim 2{ }^{\circ} \mathrm{C} / \mathrm{Ma}$ (see Figures 3 and 6), the 100 Ma cooling age difference between the analyzed garnets, in Table II, corresponds to a burial depth difference of $7 \mathrm{~km}$ at the time of $\mathrm{Nd}$ isotopic system closure in granulite sample V7. This is due to the fact that these samples would have been juxtaposed at $\sim 1750 \mathrm{Ma}$ ago (as indicated by similar $\mathrm{Rb} / \mathrm{Sr}$ biotite ages; see Figure 6 ). Therefore, a differential uplift of up to $7 \mathrm{~km}$ is inferred to have occurred between San Felix granulite samples V7 and V6 sometime after $1900 \mathrm{Ma}$ and before $1750 \mathrm{Ma}$. Using the same reasoning $(1-2$ ${ }^{\circ} \mathrm{C} / \mathrm{Ma}$ and $35^{\circ} \mathrm{C} / \mathrm{km}$ at $\mathrm{T} \leq 550{ }^{\circ} \mathrm{C}$; see Figs. 3 and 5), the $200 \mathrm{Ma}$ cooling age difference between the hornblendes analyzed by Onstott et al. (1989) implies that a differential uplift of $6-12 \mathrm{~km}$ has occurred between La Ceiba (amphibolite) rocks and neighboring domains of the Imataca Complex sometime after $1760 \mathrm{Ma}$ and before $1100 \mathrm{Ma}$ (when all samples should have been close, $<4 \mathrm{~km}$, to the surface; see Figure 6). Considering these results, a reasonable interpretation for the thermochronological data is that repeated tectonic movements played an important role on the thermal structure of the Imataca Complex.

Accordingly, the most significant mineralogical and age variations in the Imataca Complex seem to occur across shear zones which were active several times during the Proterozoic $(2.0-1.1 \mathrm{Ga}$; Ascanio, 1985; Swapp and Onstott, 1989; Gibbs and Barron, 1993) and may have been responsible for differential displacements of Imataca metamorphic rocks (e.g., Copeland et al., 1995; Dunlap et al., 1997). The thermochronological data are consistent with geolog- 
ical observations, also suggesting that differential tectonic exhumation was episodic on the shear zones. Thus long lasting periods of very low cooling rates (e.g., $\sim 1700 \mathrm{Ma} \rightarrow 1400 \mathrm{Ma}$ and $\sim 1350 \mathrm{Ma}$ $\rightarrow 1250 \mathrm{Ma}$; see Figure 6) alternate with relatively faster exhumation events (e.g., $\leq 1900 \mathrm{Ma}, \leq 1760 \mathrm{Ma}, \leq 1400 \mathrm{Ma}$ and $\leq 1170 \mathrm{Ma}$; see Figure 6) that proceeded to progressively shallower depths (as required by the overall, main cooling trend of the Imataca Complex in Figure 6). Interestingly, the inferred (maximum) ages of shear zone re-activation in the Imataca Complex generally coincide with major, continental accretion tectonic-thermal events in the Amazonian Craton (e.g., Ventuari-Tapajos: 1.95 - $1.8 \mathrm{Ga}$; Rio Negro- Juruena: 1.8 - 1.55 Ga; Rondonian - San Ignácio: 1.5 - $1.3 \mathrm{Ga}$; and Sunsás: $1.25-1.0 \mathrm{Ga}$; see Tassinari et al., 2000). During these (late) collision events, the Imataca terrane(s) should have behaved like a rigid body, and the resulting deformation was mostly concentrated on preexisting fault systems. Thus, renewed differential displacements along the main shear zones allowed relatively faster uplift of the intervening blocks, while permitting slower exhumation on the remaining Imataca Complex.

\section{Conclusions}

SHRIMP U/Pb-zircon data, coupled with Nd mean crustal residence ages, indicate that at least some of the Imataca Complex developed from mid-Archean $(\geq 3.2 \mathrm{Ga}$ ) continental protoliths which underwent considerable reworking and juvenile accretion additions during late-Archean $(\sim 2.8 \mathrm{Ga}$. This was followed by a long period of relative tectonic quiescence, from $\sim 2.8 \mathrm{Ga}$ to $\sim 2.2 \mathrm{Ga}$, before the onset of the Transamazonian orogeny which is the major event preserved in Imataca rocks.

Imataca Transamazonian granulites experienced peak metamorphic conditions of $750-800^{\circ} \mathrm{C}, 6-8 \mathrm{kbar}$ with associated transpressive shearing that leaded to northward directed thrusting and tectonic imbrication. Geochronology on zircon, pyroxene, garnet, hornblende (Onstott et al., 1989) and biotite has been used to constrain the timing of peak metamorphism at $1.98-2.05 \mathrm{Ga}$ and the average initial cooling rate of $\sim 30^{\circ} \mathrm{C} / \mathrm{Ma}$ (from $800{ }^{\circ} \mathrm{C}$ to $600{ }^{\circ} \mathrm{C}$ ). Diffusion modeling of $\mathrm{Fe}-\mathrm{Mg}$ exchange between biotite inclusions and host garnet yields (near metamorphic peak) cooling rates of $50-100$ ${ }^{\circ} \mathrm{C} / \mathrm{Ma}$, that are generally consistent with cooling rates determined from geochronology. Combining the inferred retrograde P-T path $\left(30-40{ }^{\circ} \mathrm{C} / \mathrm{km}\right)$ with the estimated (petrological/geochronological) cooling rates, suggests that after peak metamorphism large portions of the Imataca Complex were exhumed from 30 to $17 \mathrm{~km}$ at a rate of $7-2 \mathrm{~km} / \mathrm{Ma}$ after which exhumation rates progressively decreased $(15 \rightarrow 10 \mathrm{~km}$ at $0.06-0.03 \mathrm{~km} / \mathrm{Ma})$ as the rocks approached the surface. Rapid overall uplift/erosion had ceased before the rocks passed below $600-550{ }^{\circ} \mathrm{C}(2.01-1.96 \mathrm{Ga}$ ago $)$ and the remaining slow cooling represents thermo-mechanical recovery of the thinned crust on approaching isostatic equilibrium.

Large variations in mineral cooling ages seem to occur across major fault systems in the Imataca Complex, which are interpreted as to reflect episodic differential tectonic exhumation within those shear zones. Geological evidence indicates that movements along the shear zones occurred for several times during the Proterozoic and the inferred (maximum) ages of re-activation generally coincide with major continental accretion events in the Amazonian Craton. The thermochronological data, therefore, reflects the long-term thermal evolution of Imataca Complex, as conditioned by variable response to continued continental development into the Amazonian Craton during the Proterozoic.

\section{Acknowledgements}

This project was partially supported by grants from SOPEMI, Pesquisa e Exploração de Minérios S/A and PRONEX project (\# 41.96.0899.00). J.Munhá acknowledges support from Centro de
Geologia (FCUL) and FAPESP ( \# 03/00027-4). The authors also acknowledge Compania Minera SOPEVEN for his helpful support during field work and Veridiana T.S. Martins for a review of the manuscript. This paper is a contribution to research project PETROLOG (FCT-Portugal; POCTI/FEDER) and FAPESP (Thematic project \# 95/4652-2).

\section{References}

Allègre, C.J., and Ben Othman, D., 1980, Nd-Sr isotopic relationship in granitoid rocks and continental crust development: A chemical approach to orogenesis. Nature, v. 286, pp. 335-342.

Andersen, D.J., Lindsley, D.H., and Davidson, P., 1993, QUILF: A Pascal program to assess equilibria among $\mathrm{Fe}-\mathrm{Mg}-\mathrm{Mn}-\mathrm{Ti}$ oxides, pyroxenes, olivine and quartz. Computers Geosciences, v. 19, pp. 1333-1350.

Arndt, N.T., and Goldstein, S.L., 1987, Use and abuse of crust-formation ages. Geology, v. 15, pp. 893 - 895.

Ascanio, G., 1985, Yacimientos de Mineral de Hierro del Precambrico. Boletin de Geologia, Spec. Publ. V.10. Ministerio de Energia y Minas. I Simposium Amazonico, pp. 464-473.

Ben Othman, D., Polvé, M., and Allègre, C.J., 1984, Nd-Sr isotopic composition of granulites and constrains on the evolution of the lower continental crust. Nature, v. 307 , pp. 510 - 515.

Berman, R.G., 1988, Internally-consistent thermodynamic data for minerals in the system $\mathrm{Na} 2 \mathrm{O}-\mathrm{K} 2 \mathrm{O}-\mathrm{CaO}-\mathrm{MgO}-\mathrm{FeO}-\mathrm{Fe} 2 \mathrm{O} 3-\mathrm{SiO} 2-\mathrm{TiO} 2-\mathrm{H} 2 \mathrm{O}$ CO2. Journal Petrology, v. 29, pp. 445-522.

Berman, R.G., 1991, Thermobarometry using multi-equilibrium calculations: a new technique with petrologic applications. Canadian Mineralogist, v. 29 , pp. 833-855.

Berman, R.G., and Aranovich, I.Y., 1996, Optimized standard state and solution properties of minerals. I. Model calibration for olivine, orthopyroxene, cordierite, garnet and ilmenite in the system FeO-MgO-CaO-A12O3TiO2-SiO2. Contrib. Mineral. Petrol., v. 126, pp. 1-24.

Bohlen, S.R., 1987, Pressure-Temperature-time paths and a tectonic model for the evolution of granulites. Journal Geology, v. 95, pp. 617-632.

Burton, K.W., and O'Nions, R.K., 1992, The timing of mineral growth across regional metamorphic sequence. Nature, v. 357, pp. 235-238.

Chakraborty, S., and Ganguly, J., 1992, Cation diffusion in aluminosilicate garnets - experimental determination in spessartine-almandine diffusion couples, evaluation of effective binary diffusion coefficient, and applications. Contrib. Mineral. Petrol., v.111, pp. 74-86.

Chase, R., 1965, El complejo de Imataca, la anfibolita de Panamo y la trondjemita de Guri, rocas precambricas del Quadrilatero Las Adjuntas Panamo, Estado Bolivar, Venezuela. Boletin de Geologia, v. VII, n.13, MMH., Caracas.

Cherniak, D.J., Hanchar, J.M., and Watson, E.B., 1997, Diffusion of tetravalent cations in zircon. Contrib. Mineral. Petrol., v. 127, pp.383-390.

Copeland, P., Harrison, M.T., Yung, P., Kidd, W.S.F., Roden, M., and Yuquan, Z., 1995, Thermal evolution of the Gangdese batholith, southern Thibet: A history of episodic unroofing. Tectonics, v. 14, pp.223-236.

Crank, J., 1975, The Mathematics of Diffusion. Clarendon Press, Oxford. $414 \mathrm{p}$.

Cliff, R.A., 1985, Isotopic dating in metamorphic belts. Journal Geological Society London, v.142, pp.97-110.

Cordani, U.G., and Brito Neves, B.B., 1982, The geologic evolution of South America during the Archean and Early Proterozoic. Revista Brasileira de Geociĺncias, S,,o Paulo, v.12, n.11-3, pp. 78-88.

DePaolo, D. J., Linn, A. M.,and Schubbert, G., 1991, The Continental age distribuition: methods of determinig mantle separation ages from $\mathrm{Sm}-\mathrm{Nd}$ isotopic data and application to the southwestern United States. Journal Geophysical Research, v. 96, pp. 2071-2088.

Dodson, M.H., 1973, Closure temperature in cooling geochronological and petrological systems. Contrib. Mineral. Petrol., v. 40, pp. 259-264

Dodson, M.H., 1986, Closure Profiles in cooling systems. Materials Sci. Forum, v.7, pp. 145-154

Dougan, Th.W, 1977, The Imataca Complex near Cerro Bolivar, Venezuela (a calc-alkaline Archean protolith. Precambrian Research, v. 4:pp. 237268.

Dunlap, W.J., Weinberg, R.F., and Searle, M.P., 1998, Karakoram fault zone rocks cool in two phases. Journal Geological Society London. v. 155, pp. 903-912.

England, P.C., and Richardson S.W., 1980, Erosion and age dependence of continental heat flow. Geophys. J. R. Astron. Soc. V.62, pp. 421-437.

England, P.C., and Thompson, A. B., 1984, Pressure-Temperature-Time paths of regional metamorphism I: Heat transfer during the evolution of 
regions of thickened continental crust. Journal Petrology, v. 25, pp. 894928.

England, P.C., and Molnar, P., 1990, Surface uplift, uplift of rocks, and exhumation of rocks. Geology, v.18, pp. 1173-1177.

Ferry, J.M., and Spear, F.S., 1978, Experimental calibration of the partitioning of $\mathrm{Fe}$ and $\mathrm{Mg}$ between biotite and garnet. Contrib. Mineral. Petrol., v.66, pp. 113-117.

Fyfe, W.S., 1978, The evolution of the Earth's crust: Modern plate tectonics to ancient hot-spot tectonics ? Chemical Geology, v.23, pp. 89 - 114.

Ganguly, J., Cheng, W., and Chakraborty, S., 1998, Cation diffusion in aluminosilicate garnets: experimental determination in pyrope-almandina diffusion couples. Contrib. Mineral. Petrol., v. 131, 171-180.

Ganguly, J., and Tirone, M., 1999, Diffusion closure temperature and age of a mineral with arbitarary extend of diffusion: Theoretical formulation and applications. Earth Planetary Science Letters, v.170, pp. 131-140.

Gibbs, A. K., and Barron, C. N., 1983, The Guiana Shield reviewed. Episodes, v. 2, pp. 7-14

Gibbs, A. K., and Barron, C. N., 1993, The Geology of Guiana shield: New York, Oxford University Press, Oxford Monographs on Geology and Geophysics, 22, 246 p.

Harrison, T.M., and MacDougall, I., 1980, Investigations of an intrusive contact, northwest Nelson, New Zealand, 1: Thermal, chronological and isotopic constraints. Geochim. Cosmochim. Acta, v. 44, pp. 1985-2003.

Heaman, L., and Parrish R.R., 1991, U-Pb geochronology of accessory minerals. In: Applications of Radiogenic Isotope Systems to Problems in Geology. Mineralogical Association of Canada Short Course Handbook, v. 19 , pp. 59-102.

Hodges, K.V., and Spear F.S., 1982, Geothermometry, geobarometry and the Al2SiO5 triple point at Mt. Moosilauke, New Hampshire. American Mineralogist, v. 67, pp.1118-1134.

Holland, T.J.B., and Blundy, J.D., 1994, Non-ideal interactions in calcic amphiboles and their bearing on amphibole-plagioclase thermometry. Contrib. Mineral. Petrol., v. 116, pp. 433-447.

Holland, T.J.B. and Powell, R., 1998, An internally-consistent thermodynamic dataset for phases of petrological interest. Journal Metamorphic Geology, v. 16, pp. 309-344.

Hurley, P.M., Kalliokoski, J., Fairbain, H.W., and Pinson, W.H., 1972, Progress report on the age of granulite facies rocks in the Imataca Complex, Venezuela. Proceedings of the 9th Inter-Guayanas Geological Conference, pp.431-433.

Hurley, P.M., Fairbairn, H.W.,. Gaudette H.F, Mendoza, V., Martin C. B., and Espejo A., 1973, Progress report on age dating in the northern Guayana Shield, Proceedings 2nd. Latin-American Geological Conference, 1 .

Hurley, P.M., Fairbain, H.W., and Gaudette, H.E. ,1976, Progress report on early Archean rocks in Liberia, Sierra Leone, and Guayana, and their general stratigraphic setting. In: The Early History of the Earth (B.F. Windley, ed.) Chichester: Wiley, pp. 511-521.

Kalliokoski, J., 1965, Geology of North-Central Guayana Shield, Venezuela. Geological Society of America Bulletin, v. 76, pp. 1027-1050.

Knudsen, T.-L., Andersen, T., Whitehouse, M.J., and Vestin, J., 1997, Detrital zircon ages from southern Norway / Implications for the Proterozoic evolution of the southwetrn Baltic Shield. Contirb. Mineral. Petrol., v.130, pp. 47-58.

Lasaga, A.C., 1979, Multicomponent exchange and diffusion in silicates. Geochim. Cosmochim. Acta. V. 43, pp. 455-469.

Lasaga, A.C., 1983, Geospeedometry: An extension of geothermometry. In: Saxena, S.K. (Ed). Kinetics and equilibrium in mineral reactions. New York: Springer Verlag, pp.81-114.

Lee, H.Y., and Ganguly, J.,1988, Equilibrium compositions of coexisting garnet and orthopyroxene: experimental determinations in the system $\mathrm{FeO}-\mathrm{MgO}-\mathrm{Al} 2 \mathrm{O} 3-\mathrm{SiO} 2$, and applications. Journal Petrology, v.29, pp. 93-113.

Liew, T.C., and Hofman A.W., 1988, Precambrian crustal components, plutonic associations, plate environment of the Hercynian fold Belt of Central Europe: Indications from a Nd and $\mathrm{Sr}$ isotopic study. Contrib. Mineral. Petrol., v. 98, pp. 129-138.

Ludwig, K.R., 1998, Isoplot/Ex. Berkeley Geochronological Center. Special Publication 1.

McCulloch,M.T., and Wasserburg G.J., 1978, Sm-Nd and Rb-Sr chronology of continental crust formation, Science, v. 200, pp.1003-1011.

Mezger, K., Essene, E. J., and Halliday, A. N., 1992, Closure temperature of Sm-Nd system in metamorphic garnets. Earth Planetary Science Letters, v. 113 pp. $397-409$.

Montgomery, C. W., 1979, Uranium-Lead Geochronology of the Archean Imataca Series, Venezuelan Guayana Shield. Contrib. Mineral. Petrol.,v. 69, pp. 167-176.
Montgomery, C. W., and Hurley, P. M, 1978, Total-Rock U-Pb Systematics in the Imataca Series, Guayana Shield, Venezuela. Earth Planetary Science Letters, v. 39, pp. 281-290.

Montgomery, C.W., Hurley, P.M., and Fairbairn, H.W., 1977, Equilibrated domains and combined $\mathrm{Rb}-\mathrm{Sr}$ and $\mathrm{U}-\mathrm{Pb}$ systematics in the history of a granulite. Twenty-first Progress Report, for 1974-76. M.I.T. Geochronology Laboratory, pp. 1-25.

O'Nions R.K., Hamilton, P.J. and Hooker,, P.J.,1983, A Nd isotope investigation of sediments related to crustal development in the British Isles. Earth Planet. Science Letters, v. 63, pp. 229 - 240.

Onstott, T. C. and Hargraves, R. B., 1981, Proterozoic transcurrent tectonics: palaeomagnetic evidence from Venezuela and Africa. Nature, v. 289, pp. 131-136.

Onstott, T. C., Hall, C. M. and York, D., 1989, ${ }^{40} \mathrm{Ar} /{ }^{39} \mathrm{Ar}$ thermochronometry on the Imataca Complex, Venezuela. Precambrian Research, v. 42, pp. 255-291.

Paces, J.B. and Miller, J.D. Jr., 1993, Precise U-Pb ages of Duluth Complex and related mafic intrusions, northeastern Minnesota: Geochronological insights to physical petrogenetic, paleomagnetic and tectonmagmatic processes associated with the $1.1 \mathrm{Ga}$ midcontinent rift system. Journal Geophysical Research, v. 98, pp.13997-14013.

Pidgeon R.T., Nemchin, A. A., and Hitchen, G.J., 1998, Internalstructures of zircons from Archean granites from the Darling Range batholith: implications for zirco stability and interpretation of zircon U-Pb ages. Contrib. Mineral. Petrol. v. 132, pp. 288-300.

Posadas, V. G., and Kalliokoski, J., 1967, Rb/Sr ages of the Encrucijada granite intrusive into the Imataca complex, Venezuela. Earth Planetary Science Letters, v. 2, pp. 210-214.

Richter, F.M., 1984, Regionalized models for the thermal evolution of the Earth. Earth planetary Science Letters, v. 68, pp. 471-484.

Sato, K., Tassinari, C.C.G., Kawashita, K., and Petronilho, L., 1995, O método geocronológico Sm-Nd no IG/USP e suas aplicações. Anais da Academia Brasileira de Ciências, v. 67, n. 3, pp. 315-336.

Spear, F.S., 1991, On the interpretation of peak metamorphic temperatures in the light of garnet diffusion during cooling. Journal Metamorphic Geology, v. 9 , pp. 379-388

Spear, F.S., and Florence, F.P., 1992, Thermobarometry in granulites: Pitfalls and new approach. Precambrian Research, v. 55, pp. 209-241.

Spear, F.S., and Markusen, J.C., 1997, Mineral zoning, P-T-X-M phase relations and metamorphic evolution of some Adirondack granulites, New York. Journal Petrology, v. 38, pp. 757-783.

Spear, F.S., and Parrish, R.R., 1996, Petrology and cooling rates of the Vallalla Complex, British Columbia, Canada. Journal Petrology, v. 37, pp. 733-765.

Stern, R.A., 1998, High-resolution SIMS determination of radiogenic traceisotope ratios in minerals. In: L.J. Cabri and D.J. Vaughan (editors): Modern approaches to ore and environmental mineralogy. Mineralogical Association of Canada, Short Course Handbook, v. 27, pp. 241-268.

Swapp, S. M., and Onstott, T. C., 1989, P-T-time characterization of the Transamazonian orogeny in the Imataca Complex, Venezuela. Precambrian Research, v. 42, pp. 293-314.

Tassinari, C. C. G., and Macambira, M. J. B ,1999, Geochronological provinces of the Amazonian Craton. Episodes v. 22, n. 3, pp. 174-182.

Tassinari, C. C. G., Bettencourt, J. S., Geraldes, M. C., Macambira, M. J. B., and Lafon, J. M., 2000, The Amazonian Craton. In: Cordani, U. G., Milani, E. J., Thomaz Filho, A. and Campos, D. A., (Eds.), Tectonic Evolution of South America, pp. 41-96, (31st International Geological Congress, 2000).

Tassinari, C. C. G., Mellito, K. M., and Babinski, M., 2003, Age and origin of the $\mathrm{Cu}(\mathrm{Au}-\mathrm{Mo}-\mathrm{Ag})$ Salobo $3 \mathrm{~A}$ ore deposit, Caraj-s Mineral Province, Amazonian Craton, northern Brazil. Episodes v.26, n.1 pp. 2 ñ 9.

Taylor S.R., and McLennan, S.M., 1985, The Continental Crust: Its Composition and Evolution, Blackwell Scientific. Boston, Mass., 312 p.

Teixeira, W., Tassinari, C.C.G., and Mondin, M., 2002, Características isotópicas ( $\mathrm{Nd}$ e $\mathrm{Sr}$ ) do plutonismo intrusivo no extremo NW do Cráton Amazônico, Venezuela, e implicaçõespara a evolução paleoproterozóica Boletim do Instituto de Geociíncias da USP, Ser. Cient., v.2, pp. 131-141.

Van Orman, J.A., Grove, T.L., and Shimizu, N., 2001, Rare earth element diffusion in diopside: Influence of temperature, pressure, and ionic radios, and an elastic model for diffusion in silicates. Contrib. Mineral. Petrol., v. 141, pp. 687-703.

Veizer J., and Jansen, S.L., 1979, Basement and sedimentary recycling and continental evolution. Journal Geology, v. 87, pp. 341 - 370.

Williams, I.S., 1998, U-Th-Pb geocronology by ion microprobe. In: M.A. McKibben, W.C.P. Shanks III and W.I. Ridley (Eds.), Applications of microanalytical techniques to understanding mineralizing processes. Society Economic Geologists Short Course 7, pp. 1-35. 
Wilson, C.R., and Smith, D., 1984, Cooling rate estimates from mineral zonation: Resolving power and applications. In: Kornprobst,J.(Ed). Kimberlites II: The Mantle and Crust-Mantle Relationships. Amsterdan, Elsevier, pp. 265-275.

Wynn, J.C., Sidder, G.B., Gray, F., Page, N., and Mendoza, V., 1993, Geology and mineral deposits of the Venezuelan Guayana Shield. U.S. Geological survey Bulletin, n. B2124, pp. A1-a7.

\section{Colombo Celso Gaeta Tassinari is} full professor of isotope geochemistry at the Institute of Geoscience of University of São Paulo, Brasil and vice-Director of the same Instititut. He is member of Geochronological Research Center of the same university and he works on isotope geology applied to crustal evolution and metallogenesis. He was co-leader of the IGCP-204 "Evolution of the Amazonian Craton" and IGCP 342 "Isotope on South American Ore Deposits". He is member of the Brazilian Academy of Sciences and Lisbon Academy of Sciences and Scientific Researcher $1 A$ of the Brazilian National Research Council, CNPq.

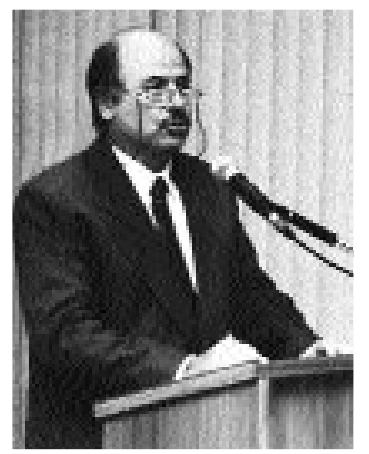

José Manuel U. Munhá is full professor of geochemistry and petrology at the Faculty of Sciences (University of Lisbon, Portugal). He is currently Head of the Geological Center research unit of the same university. His research activities are mainly concerned with the geodynamic evolution of oceanic islands and the Iberian Variscides (high-pressure metamorphism and ophiolites) and thermochronology in fold belts. Member of the Lisbon Academy of Sciences, Portugal.

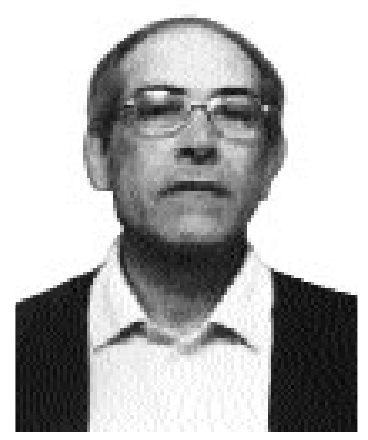

Wilson Teixeira is Full Professor of the Department of Mineralogy and Geotectonics and member of the Geochronological Research Center of the Institute of Geosciences USP. Member of the Brazilian Academy of Sciences and Scientific Researcher $1 A$ of the Brazilian National Research Council, CNPq. Co-leader of the IGCP-204 "Evolution of the Amazonian Craton. UNESCO/IUGS (19831987). Main areas of interest: geochronology and crustal evolution of Archean and Proterozoic terranes and tectonics of Precambrian mafic dikes.

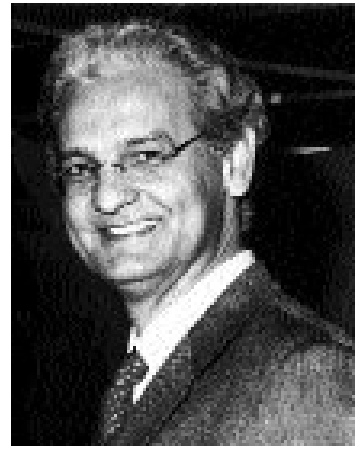

\title{
CALL FOR PAPERS
}

Episodes is the quarterly science and news journal of the International Union of Geological Sciences (IUGS). It focuses on the publication of results of scientific research and other information addressing issues of interest to the global earth-science community. Special emphasis is given to topics involving geological aspects of population growth and economic development and their resulting impacts on or implications for society. As the principal publication of the IUGS, Episodes also carries information about IUGS scientific programs and activities to the extent necessary to communicate effectively with the worldwide IUGS constituency.

Contributions of the following types of manuscripts are here solicited:

- review papers

- scientific articles

- conference reports

- news and views

- letters to editor

- book reviews

- information on training courses (especially those geared to participants from developing countries)

- noteworthy new publications, including national or regional geologic maps

Episodes also invites photos or other images for the front cover. Photos must be of high technical quality and tell an interesting geological story. A color transparency and one color print (at least $9 \mathrm{~cm} \times 12.6 \mathrm{~cm}$ ) are required for submission, which should be supplemented with a short explanatory paragraph (no more than 100 words).

Please address all contributions to:

\author{
The Editor \\ Episodes \\ P. O. Box 823, 26 Baiwanzhuang Road \\ 100037 Beijing, CHINA \\ Tel: +86-10-68320827; +86-10-68329084 \\ Fax: +86-10-68328928; \\ E-mail: episodes@public2.bta.net.cn.
}

